\section{Short-term Effects of Composted Cattle Manure or Cotton Burr on Growth, Physiology, and Phytochemical of Spinach}

\author{
Chenping $\mathrm{Xu}^{1}$ and Beiquan Mou \\ U.S. Department of Agriculture, Agricultural Research Service, U.S. \\ Agricultural Research Station, 1636 East Alisal Street, Salinas, CA 93905
}

Additional index words. Spinacia oleracea, antioxidant, chlorophyll, soil amendments

\begin{abstract}
Compost is increasingly used in horticultural crop production as soil conditioner and fertilizer because of its contribution to agriculture sustainability. The short-term (35 days after transplanting) effects of composted cattle manure or cotton burr on growth, physiology, and phytochemical of spinach (Spinacia oleracea L.) were evaluated in a greenhouse. Composted cattle manure at $5 \%$ or $10 \%$ mix rate $(5 \mathrm{Ca}$ or $10 \mathrm{Ca})$ greatly enhanced spinach growth as indicated by increased leaf number, area, fresh and dry weights (FW and DW), shoot FW and DW, and root DW. They also increased water use efficiency (WUE) and shoot:root ratio, and improved the photochemistry of mature leaves. Chlorophyll content also increased under 10Ca treatment. Composted cotton burr also improved spinach growth but only at $10 \%$ amendments $(10 \mathrm{Co})$, and was less efficient than composted cattle manure. Specific leaf area (SLA) decreased and succulence increased under all compost amendment indicating that compost could improve spinach quality. All soil amendments reduced the content of total phenolic and anthocyanin, while only $10 \mathrm{Co}$ and $5 \mathrm{Ca}$ treatments decreased flavonoid content and total antioxidant capacity. The content of carotenoid and protein increased in $10 \mathrm{Ca}$ treatment and amino acid content increased under both $5 \mathrm{Ca}$ and $10 \mathrm{Ca}$ treatments. The results indicated that compost, especially composted cattle manure mixed at $10 \%$, improved spinach production and quality, and with proper application rate enhanced nutritional value by increasing carotenoid, protein, and amino acid contents while having little effect on total antioxidant capacity.
\end{abstract}

Intensive applications of synthetic fertilizers to increase crop productivity have been widely practiced to meet food demand around the world. However, prolonged intensive cultivation with excess fertilizer can cause considerable damage to the ecology of agricultural systems such as soil degradation associated with depletion of soil organic matter (Herrick, 2000; Kirschenmann, 2010; Liu et al., 2006). Reduced soil organic matter frequently results in lower soil biological activity and deterioration of physical and chemical properties, gradually leading to loss of soil fertility and reduction of crop production (Liu et al., 2006; Reeves, 1997). In this context, restoring and maintaining soil organic matter is critical for the long-term soil fertility and crop production. The use of organic soil amendments to improve soil fertility and enhance crop yield has gained

Received for publication 21 July 2016. Accepted for publication 12 Oct. 2016.

The technical assistance of Phi Diep and Frances Wong, and critical review by James McCreight and Renee Eriksen are greatly appreciated.

Mention of trade names or commercial products in this publication is solely for the purpose of providing specific information and does not imply recommendation or endorsement by the U.S. Department of Agriculture.

USDA is an equal opportunity provider and employer.

${ }^{1}$ Corresponding author. E-mail: cpxu1999@hotmail. com. considerable momentum for agroecological sustainability (D'Hose et al., 2012; Emmerling et al., 2010; Hargreaves et al., 2008).

Composting is an aerobic process that relies on high temperatures, thermophilic and mesophilic bacteria to sanitize, decompose and stabilize organic material, which primarily are municipal or agricultural wastes. The main uses of composts are as soil amendment and organic fertilizer for horticultural crops. Application of compost can improve soil properties such as organic matter, water and nutrient storage capacity, aggregate ability, resistance to compaction and erosion, infiltration and aeration, and resistance to soil-borne diseases (Hargreaves et al., 2008; Mehta et al., 2014; Whalen et al., 2003). Compost also is favorable for the development of soil macrofauna which play a key role in improving soil quality (Albiach et al., 2000; Birkhofer et al., 2008; Emmerling et al., 2010). As organic fertilizer, compost slowly releases nutrients which may be taken up by crops and thus result in improved agroecosystem productivity (Hargreaves et al., 2008; McLauchlan, 2006).

Many researchers have investigated the influences of compost as soil amendments on growth, yield, and quality of horticultural crops, especially vegetables (Hargreaves et al., 2008; Herencia et al., 2011; Montemurro et al., 2015). Although positive effects on crop growth, yield, and nutrition quality have been observed in many studies, others still have found that compost did not provide improvements. Overall, these studies involved different compost derived from a wide range of resources, including municipal solid waste, cattle or poultry manure, crop residues, and mixture of manure and crop residues. The compost was produced by a range of different groups. Also compost effects were altered by soil types (Zhang et al., 2014). Hence, any variations among studies

Table 1. Physical and chemical properties on dry weight basis of original soil and composted cattle manure and cotton burr before treatments, and soil samples from each treatment after harvesting.

\begin{tabular}{|c|c|c|c|c|c|c|c|c|}
\hline \multirow[b]{2}{*}{ Properties } & \multicolumn{3}{|c|}{ Initial } & \multicolumn{5}{|c|}{ After harvest } \\
\hline & Soil & $\mathrm{CCB}$ & $\mathrm{CCM}$ & Soil & $5 \mathrm{Co}$ & $10 \mathrm{Co}$ & $5 \mathrm{Ca}$ & $10 \mathrm{Ca}$ \\
\hline Total N (\%) & - & 0.92 & 2.5 & - & - & - & - & - \\
\hline Available $\mathrm{N}(\mathrm{mg} / \mathrm{kg})$ & 48 & - & - & 6.0 & 8.0 & 9.5 & 8.5 & 11.0 \\
\hline $\mathrm{NH}_{4}-\mathrm{N}(\mathrm{mg} / \mathrm{kg})$ & 4.6 & $<10$ & 250 & 4.7 & 6.0 & 7.2 & 7.1 & 8.0 \\
\hline $\mathrm{NO}_{3}-\mathrm{N}(\mathrm{mg} / \mathrm{kg})$ & 43 & 430 & 380 & $<2$ & 2.0 & 2.2 & $<2$ & 3.0 \\
\hline $\mathrm{P}(\mathrm{mg} / \mathrm{kg})$ & 39 & 2,200 & 15,000 & 32 & 50 & 63 & 130 & 200 \\
\hline $\mathrm{K}(\mathrm{mg} / \mathrm{kg})$ & 79 & 12,000 & 29,000 & 67 & 180 & 270 & 260 & 530 \\
\hline $\mathrm{Ca}(\mathrm{g} / \mathrm{kg})$ & 1.0 & 35 & 44 & 1.0 & 1.4 & 1.6 & 1.1 & 1.2 \\
\hline $\mathrm{Mg}(\mathrm{mg} / \mathrm{kg})$ & 140 & 5,200 & 10,000 & 130 & 170 & 210 & 180 & 250 \\
\hline $\mathrm{SO}_{4}(\mathrm{mg} / \mathrm{kg})$ & 32 & 2,600 & 11,000 & 16 & 41 & 40 & 49 & 65 \\
\hline $\mathrm{Cu}(\mathrm{mg} / \mathrm{kg})$ & 0.53 & 45 & 47 & 0.56 & 0.58 & 0.72 & 0.65 & 0.89 \\
\hline $\mathrm{Zn}(\mathrm{mg} / \mathrm{kg})$ & 2.6 & 64 & 220 & 2.9 & 3.0 & 3.9 & 3.9 & 6.1 \\
\hline $\mathrm{Fe}(\mathrm{mg} / \mathrm{kg})$ & 32 & 10,000 & 6,700 & 25 & 30 & 34 & 60 & 98 \\
\hline $\mathrm{Mn}(\mathrm{mg} / \mathrm{kg})$ & 13 & 210 & 220 & 12 & 10 & 12 & 12 & 19 \\
\hline $\mathrm{B}(\mathrm{mg} / \mathrm{kg})$ & 0.27 & 20 & 24 & 0.30 & 0.51 & 0.74 & 0.44 & 0.70 \\
\hline $\mathrm{Na}(\mathrm{mg} / \mathrm{kg})$ & 67 & 580 & 13,000 & 66 & 77 & 78 & 120 & 190 \\
\hline $\mathrm{Cl}(\mathrm{mg} / \mathrm{kg})$ & 55 & 3,300 & 24,000 & 28 & 44 & 43 & 85 & 125 \\
\hline $\mathrm{pH}$ & 6.8 & 8.0 & 8.2 & 7.3 & 7.5 & 7.6 & 7.3 & 7.4 \\
\hline $\mathrm{EC}(\mathrm{dS} / \mathrm{m})$ & 1.9 & 4.9 & 23 & 0.58 & 0.96 & 0.93 & 1.2 & 1.7 \\
\hline Organic matter $(\%)$ & 2.3 & 18.2 & 37.8 & 2.4 & 2.9 & 3.3 & 3.2 & 3.5 \\
\hline Organic carbon $(\%)$ & 1.4 & 9.1 & 20 & 1.4 & 1.7 & 1.9 & 1.9 & 2.1 \\
\hline Bulk density $(\mathrm{g} / \mathrm{mL})$ & 1.22 & 0.77 & 0.64 & 1.17 & 1.16 & 1.08 & 1.18 & 1.08 \\
\hline CEC (meq/100 g) & 6.9 & - & - & 6.7 & 9.3 & 11.0 & 8.0 & 11.0 \\
\hline WHC $\left(\mathrm{g} \mathrm{H}_{2} \mathrm{O} / 100 \mathrm{~g}\right)$ & 7.00 & - & - & 6.85 & 7.43 & 7.62 & 7.58 & 7.85 \\
\hline $\mathrm{C}: \mathrm{N}$ ratio & - & 9.9 & 8.0 & - & - & - & - & - \\
\hline Moisture (\%) & - & 16.8 & 13.3 & - & - & - & - & - \\
\hline
\end{tabular}

$\mathrm{EC}=$ electrical conductivity; $\mathrm{CEC}=$ cation exchange capacity; $\mathrm{WHC}=$ water-holding capacity; $\mathrm{CCB}=$ composted cotton burr; $\mathrm{CCM}=$ composted cattle manure; $5 \mathrm{Ca}$ or $10 \mathrm{Ca}=$ soil amended with $5 \%$ or $10 \%(\mathrm{v} / \mathrm{v})$ composted cattle manure; $5 \mathrm{Co}$ or $10 \mathrm{Co}=$ soil amended with $5 \%$ or $10 \%(\mathrm{v} / \mathrm{v})$ composted cotton burr. 
Table 2. Effects of composted cattle manure or cotton burr as soil amendments on spinach growth $35 \mathrm{~d}$ after transplanting.

\begin{tabular}{|c|c|c|c|c|c|c|c|c|c|c|}
\hline \multirow[b]{2}{*}{$\mathrm{Trt}^{\mathrm{z}}$} & \multicolumn{4}{|c|}{ Leaf } & \multicolumn{4}{|c|}{ Shoot } & \multirow[b]{2}{*}{ Root DW (g) } & \multirow{2}{*}{$\begin{array}{l}\text { Shoot/root } \\
\text { DW ratio }\end{array}$} \\
\hline & Number & Area $\left(\mathrm{cm}^{2}\right)$ & FW (g) & DW (g) & FW (g) & DW (g) & $\mathrm{DW} / \mathrm{FW}$ & WUE $(\mathrm{mg} / \mathrm{mL})$ & & \\
\hline Control & $14.0 \pm 0.27 \mathrm{c}^{\mathrm{y}}$ & $155 \pm 5 \mathrm{~d}$ & $8.7 \pm 0.27 \mathrm{~d}$ & $1.5 \pm 0.09 \mathrm{~d}$ & $11 \pm 0.4 \mathrm{~d}$ & $1.8 \pm 0.10 \mathrm{~d}$ & $0.175 \pm 0.004 \mathrm{a}$ & $3.4 \pm 0.13 \mathrm{e}$ & $0.56 \pm 0.019 \mathrm{bc}$ & $3.2 \pm 0.12 b$ \\
\hline $5 \mathrm{Co}$ & $14.5 \pm 0.33 \mathrm{bc}$ & $173 \pm 6 \mathrm{~d}$ & $10.2 \pm 0.42 \mathrm{~d}$ & $1.9 \pm 0.08 \mathrm{~d}$ & $12 \pm 0.5 \mathrm{~d}$ & $2.3 \pm 0.10 \mathrm{~d}$ & $0.164 \pm 0.002 \mathrm{bc}$ & $4.3 \pm 0.25 \mathrm{~d}$ & $0.52 \pm 0.051 \mathrm{c}$ & $4.8 \pm 0.72 \mathrm{ab}$ \\
\hline $10 \mathrm{Co}$ & $15.3 \pm 0.56 b$ & $206 \pm 12 c$ & $13.7 \pm 1.10 \mathrm{c}$ & $2.4 \pm 0.23 \mathrm{c}$ & $17 \pm 1.3 \mathrm{c}$ & $2.9 \pm 0.26 \mathrm{c}$ & $0.162 \pm 0.006 \mathrm{bc}$ & $5.2 \pm 0.32 \mathrm{c}$ & $0.57 \pm 0.025 \mathrm{bc}$ & $5.0 \pm 0.25 \mathrm{a}$ \\
\hline $5 \mathrm{Ca}$ & $17.0 \pm 0.38 \mathrm{a}$ & $256 \pm 16 b$ & $18.0 \pm 1.40 \mathrm{~b}$ & $2.9 \pm 0.20 \mathrm{~b}$ & $21 \pm 1.7 b$ & $3.5 \pm 0.25 b$ & $0.157 \pm 0.001 \mathrm{c}$ & $6.6 \pm 0.38 b$ & $0.68 \pm 0.030 \mathrm{~b}$ & $5.1 \pm 0.14 \mathrm{a}$ \\
\hline $10 \mathrm{Ca}$ & $16.5 \pm 0.57 \mathrm{a}$ & $342 \pm 12 \mathrm{a}$ & $22.8 \pm 0.89 \mathrm{a}$ & $3.5 \pm 0.14 \mathrm{a}$ & $27 \pm 1.0 \mathrm{a}$ & $4.1 \pm 0.15 \mathrm{a}$ & $0.168 \pm 0.005 \mathrm{ab}$ & $9.1 \pm 0.13 \mathrm{a}$ & $0.81 \pm 0.082 \mathrm{a}$ & $5.6 \pm 0.96 \mathrm{a}$ \\
\hline
\end{tabular}

FW = fresh weight; DW = dry weight; WUE = water use efficiency.

${ }^{\mathrm{z}}$ Treatments $=5 \mathrm{Ca}$ or $10 \mathrm{Ca}$, soil amended with $5 \%$ or $10 \%(\mathrm{v} / \mathrm{v})$ composted cattle manure; $5 \mathrm{Co}$ or $10 \mathrm{Co}$, soil amended with $5 \%$ or $10 \%(\mathrm{v} / \mathrm{v})$ composted cotton burr.

y Values followed by standard error, different letters indicate significant difference at $P \leq 0.05$ according to Duncan's multiple range test.

may be attributed to the different compost and/or soil used.

Spinach (S. oleracea L.) is an important short-season leafy green vegetable that contains large quantities of bioactive compounds and nutrients. Literature on spinach affected by compost is very scarce. The current study aims to assess the short-term effects of composted cattle manure or cotton burr, as soil amendments, on spinach growth, physiology, and phytochemicals.

\section{Materials and Methods}

Plant materials and treatments. Two trials, each with four replications, were conducted from 30 Mar. to 14 May 2015 and 13 Apr. to 28 May 2015, in a greenhouse located in Salinas, CA (lat. $36^{\circ} 40^{\prime} 40^{\prime \prime} \mathrm{N}$, long. $\left.121^{\circ} 39^{\prime} 20^{\prime \prime} \mathrm{W}\right)$. The average temperature ranged from 16 to $34{ }^{\circ} \mathrm{C}$ and relative humidity ranged from $20 \%$ to $80 \%$. The greenhouse was supplemented with light of a 12-h photoperiod with $400 \mu \mathrm{mol} \cdot \mathrm{m}^{-2} \cdot \mathrm{s}^{-1}$ photosynthetic photon flux at canopy level (Sun System 3; Sunlight Supply, Vancouver, WA).

There were five treatments in this experiment. 1) Control: soil of sandy loam from field without amendments. 2) 5Co: soil mixed with $5 \%(\mathrm{v} / \mathrm{v})$ of commercially composted cotton burrs (Soil Mender Products, Tulia, TX). 3) 10Co: soil mixed with $10 \%(\mathrm{v} / \mathrm{v})$ of composted cotton burrs. 4) 5Ca: soil mixed with $5 \%(\mathrm{v} / \mathrm{v})$ of commercially composted cattle manure (Soil Mender Products, Tulia, TX). 5) 10Ca: soil mixed with $10 \%(\mathrm{v} / \mathrm{v})$ of composted cattle manure. For each trial, plastic pots $(2.5 \mathrm{~L})$ were filled with $3 \mathrm{~kg}$ different mixture of soil and compost amendments, and watered just to field capacity 2-weeks before transplanting. Uniformsized spinach seedlings (cv. Crocodile; W. Atlee Burpee \& Co, Warminster) were transplanted into pots 10 -d after sowing in rock wool cells (Grodan Group, Roermond, the Netherlands); Plants were thinned to one plant per pot 1 week after transplanting. Plants were rotated and irrigated twice weekly and irrigation volumes were determined by weighing each pot at field capacity and again just before irrigation. The weight loss per pot was assumed to equal total evapotranspiration (ET), and its equivalent amount was applied for each pot.

Soil and compost analysis. The untreated field soil and compost samples were collected before treatments were applied, and the soil
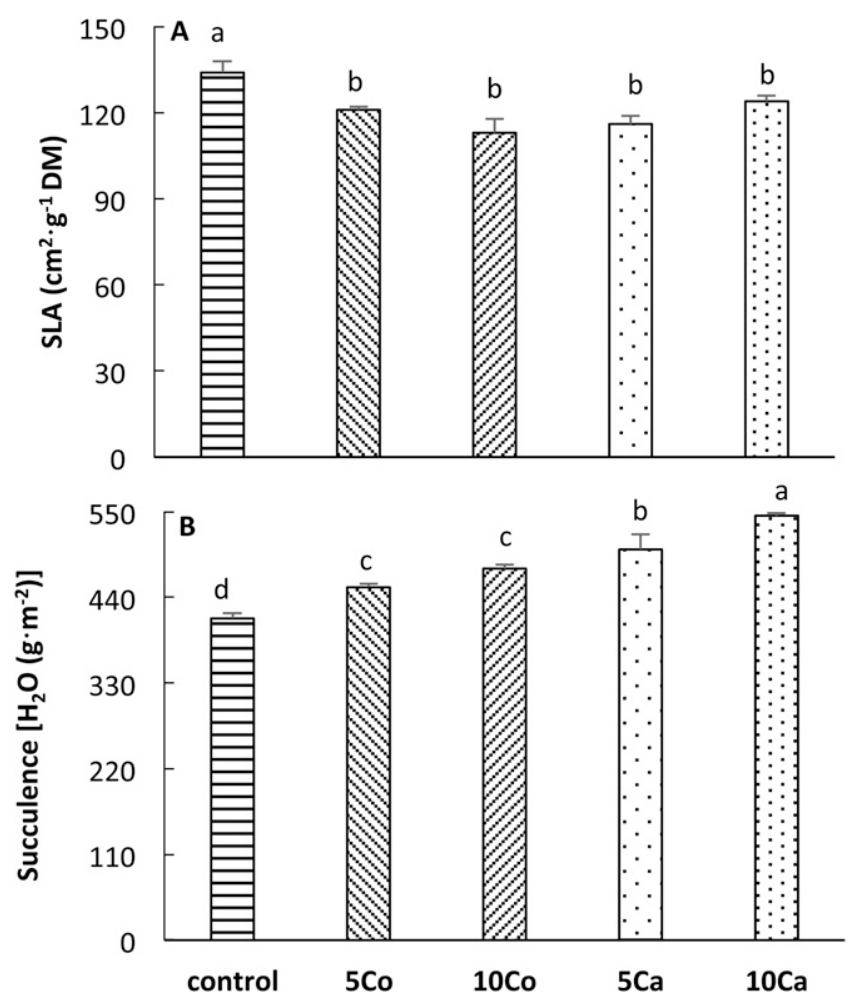

Fig. 1. Effect of composts on (A) specific leaf area (SLA) and (B) succulence $35 \mathrm{~d}$ after transplanting. The values are means of eight replicates \pm SE. Different letters on top of bars indicate significant difference at $P \leq 0.05$ according to Duncan's multiple range test. $5 \mathrm{Co}$ or $10 \mathrm{Co}$ : soil mixed $5 \%$ or $10 \%(\mathrm{v} / \mathrm{v})$ cotton burr compost. $5 \mathrm{Ca}$ or $10 \mathrm{Ca}$ : soil mixed with $5 \%$ or $10 \%(\mathrm{v} / \mathrm{v})$ cattle manure compost.

samples from different treatments were also collected using a soil sampler after harvesting. One soil core (diameter: $2.6 \mathrm{~cm}$; length: $15 \mathrm{~cm}$ ) was collected from each pot and four soil cores from each treatment were mixed together as one composite sample for determination of macro- and micronutrients, $\mathrm{pH}$, electrical conductivity (EC), organic matter and carbon, cation exchange capacity (CEC), and water holding capacity (WHC) by a commercial laboratory (Soil Control Laboratories, Watsonville, CA).

Growth and physiology measurements. Five weeks after transplanting in each trial, leaf maximum photochemical efficiency $\left(\mathrm{F}_{\mathrm{v}} / \mathrm{F}_{\mathrm{m}}\right)$, photochemical yield [Y (II)], and electron transport rate (ETR) were measured with a fluorometer (MINI-PAM-II fluorometer; Heinz Walz, Effeltrich, Germany) on the first, second, and third pair of leaves from the bottom of each plant. Leaf $F_{v} / F_{m}$ was measured after leaves were adapted in darkness for $30 \mathrm{~min}$. Then plants were harvested to measure leaf number, area, FW and DW, shoot FW and DW, and root DW. Sample DW was measured after drying at $65^{\circ} \mathrm{C}$ for $3 \mathrm{~d}$. Leaf area was measured with a leaf area meter (CI-202 laser area meter; CID BioScience Inc., Camas, WA). Irrigation WUE was calculated as: $\mathrm{WUE}=$ shoot $\mathrm{FW} /$ water used or ET.

Leaf discs were collected using a cork borer from the four largest leaves of each plant to measure relative water content (RWC), SLA, succulence, chlorophyll content, and nutritional values. SLA was calculated as: SLA = leaf area/DW (Evans, 1972). Leaf RWC was calculated as: RWC (percent) = $100 \times[(\mathrm{FW}-\mathrm{DW}) /(\mathrm{TM}-\mathrm{DW})]$, where $\mathrm{TM}$ is turgid mass after being soaked in water for $4 \mathrm{~h}$ at $4{ }^{\circ} \mathrm{C}$ (Barr and Weatherley, 1962). Succulence was calculated as water content per unit leaf area (Longstreth and Nobel, 1979). Leaf pigments were extracted with methanol and 
absorbance of extraction was measured at 665,652 , and $470 \mathrm{~nm}\left(\mathrm{~A}_{665}, \mathrm{~A}_{652}\right.$, and $\mathrm{A}_{470}$ ) with a spectrophotometer (Spectronic Genesys; Spectronic Instruments, Rochester, NY). Chlorophyll a, b, and carotenoid contents $\left(\mathrm{C}_{\mathrm{a}}, \mathrm{C}_{\mathrm{b}}\right.$, and $\left.\mathrm{C}_{\mathrm{x}}\right)$ were calculated using the formula described by Lichtenthaler (1987): $C_{a}$ (milligrams per liter $)=16.72 \mathrm{~A}_{665}-9.16 \mathrm{~A}_{652} ; \mathrm{C}_{\mathrm{b}}$ (milligrams per liter $)=34.09 \mathrm{~A}_{652}-15.28 \mathrm{~A}_{665}$; $\mathrm{C}_{\mathrm{x}}$ (milligrams per liter) $=\left(1000 \mathrm{~A}_{470}-\right.$ $\left.1.63 \mathrm{C}_{\mathrm{a}}-104.96 \mathrm{C}_{\mathrm{b}}\right) / 221$.

Phytochemical analyses. Leaf samples were soaked in liquid nitrogen immediately after harvest and stored at $-80{ }^{\circ} \mathrm{C}$. Phytochemicals were extracted from about $2 \mathrm{~g}$ of sample material with $15 \mathrm{~mL}$ acidified methanol $(1 \% \mathrm{HCl})$ using a homogenizer (Polytron; Kinematica AG, Schweiz, Switzerland), then incubated in darkness at $-20{ }^{\circ} \mathrm{C}$ overnight. After centrifuging at $9070 g_{n}$ for 15 min, the supernatant was collected for the analysis of nutritional values. Its $\mathrm{A}_{535}$ was measured for total betacyanin content. Results were calculated using a molar extinction coefficient of 65,000 (Schwartz and von Elbe, 1980). The antioxidant capacity was measured by the method of ferric reducing ability of plasma (Benzie and Strain, 1996). $10 \mathrm{~mm}$ 2,4,6-tris-2,4,6-tripyridyl-2-triazine (TPTZ) and $20 \mathrm{~mm}$ ferric chloride was diluted in $300 \mathrm{~mm}$ sodium acetate buffer ( $\mathrm{pH}$ 3.6) at a ratio of $1: 1: 10$. Extracts $(25 \mu \mathrm{L})$ were added to $2 \mathrm{~mL}$ TPTZ solution, and $\mathrm{A}_{593}$ was determined after 4.5 min-reaction. Trolox (6-hydroxy-2,5,7,8-tetramethylchroman-2carboxyl acid) equivalent standard curve was prepared.

For total phenolics content, $0.1 \mathrm{~mL}$ extract was added to a mixture of $0.15 \mathrm{~mL}$ $\mathrm{H}_{2} \mathrm{O}$ and $0.75 \mathrm{~mL}$ of $1: 10$ diluted FolinCiocalteu reagent (Sigma-Aldrich, St. Louis, MO). After $6 \mathrm{~min}, 0.60 \mathrm{~mL}$ of $7.5 \%$ (w/v) $\mathrm{Na}_{2} \mathrm{CO}_{3}$ was added and vortexed, then the mixture was incubated at $45^{\circ} \mathrm{C}$ in a water bath for $10 \mathrm{~min}$. Samples were allowed to cool to room temperature before reading $\mathrm{A}_{765}$ (Slinkard and Singleton, 1997). A standard curve was prepared from a freshly made gallic acid equivalent (GAE) solution. For total flavonoid content, $0.20 \mathrm{~mL}$ extract was mixed with $0.85 \mathrm{~mL}$ distilled water and $50 \mu \mathrm{L}$ of $5 \% \mathrm{NaNO}_{2}$. After $6 \mathrm{~min}, 100 \mu \mathrm{L}$ of $10 \%$ $\mathrm{AlCl}_{3} 6 \mathrm{H}_{2} \mathrm{O}$ was added, and after another $5 \mathrm{~min} 0.35 \mathrm{~mL}$ of $1 \mathrm{M} \mathrm{NaOH}$ and $0.20 \mathrm{~mL}$ distilled water were added, then $\mathrm{A}_{510}$ was measured immediately (Dewanto et al., 2002). A (+)-catechin hydrate equivalents standard curve was prepared from a freshly made solution.

Protein and amino acid contents. Leaf samples (about $2 \mathrm{~g}$ ) were homogenized in $15 \mathrm{~mL} 0.2 \mathrm{~m}$ phosphate buffer ( $\mathrm{pH}$ 6.6) using a homogenizer. After centrifuging at $9070 g_{\mathrm{n}}$ for $15 \mathrm{~min}$, the supernatant was collected to measure the content of protein and amino acid. Amino acid content was determined using the ninhydrin method (Yokoyama and Hiramatsu, 2003). A 1\% w/v ninhydrin stock solution was prepared in ethanol containing $0.025 \% \mathrm{w} / \mathrm{v}$ ascorbic acid. A working ninhydrin
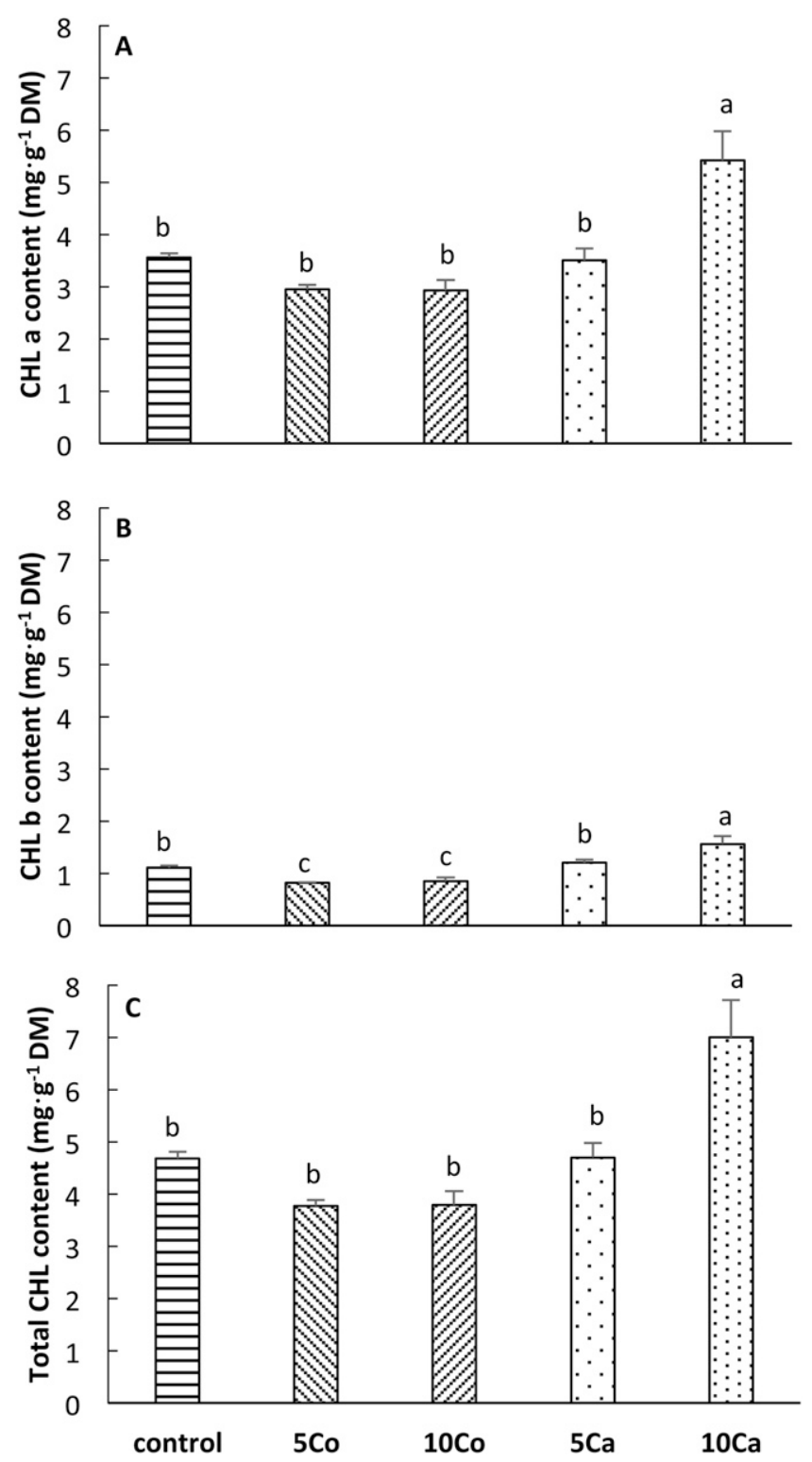

Fig. 2. Effect of composts on spinach (A) chlorophyll (CHL) a, (B) CHL b, and (C) total CHL content $35 \mathrm{~d}$ after transplanting. The values are means of eight replicates $\pm \mathrm{SE}$. Different letters on top of bars indicate significant difference at $P \leq 0.05$ according to Duncan's multiple range test. 5Co or 10Co: soil mixed $5 \%$ or $10 \%(\mathrm{v} / \mathrm{v})$ cotton burr compost. $5 \mathrm{Ca}$ or $10 \mathrm{Ca}$ : soil mixed with $5 \%$ or $10 \%(\mathrm{v} / \mathrm{v})$ cattle manure compost.

solution was prepared immediately before use by adding two parts of $0.4 \mathrm{M}$ sodium acetate buffer ( $\mathrm{pH}$ 5.0) to one part of ninhydrin stock solution. Extract or standard glutamate solution $(50 \mu \mathrm{L})$ was added to $2.9 \mathrm{~mL}$ ninhydrin work solution and the mixture was heated at $95{ }^{\circ} \mathrm{C}$ for $10 \mathrm{~min}$. The solution was cooled and $\mathrm{A}_{570}$ was measured. Protein content was determined according to the method of Bradford (1976) using bovine serum albumin as standard.

Statistical analysis. A complete randomized design was used for this experiment. Each biological replicate contained one pot and each treatment contained four replicate pots for each trial. The interaction between the two trials was not significant by analysis of variance using the general linear model so data were pooled together and eight replications were considered in the data analysis. Treatment means were separated by Duncan's multiple range test at the 0.05 level of probability using the JMP program, version 5 (SAS Institute Inc., Cary, NC).

\section{Results}

Soil physical and chemical properties. The physical and chemical properties of composted cattle manure and cotton burr are listed in Table 1. Compared with cotton burr compost, cattle manure compost contained numerically higher contents of total $\mathrm{N}$, $\mathrm{P}, \mathrm{K}, \mathrm{Mg}, \mathrm{SO}_{4}$, and $\mathrm{Zn}$. Also, cattle manure compost had more organic matter and carbon than cotton burr compost. However, EC was much higher in cattle manure compost than in cotton burr compost, which might result from 
high contents of $\mathrm{Na}$ and $\mathrm{Cl}$ in cattle manure compost. The C:N ratio was 9.9 for composted cotton burr and 8.0 for composted cattle manure.

After harvesting, both $5 \mathrm{Co}$ and $10 \mathrm{Co}$ treatments left numerically high content of $\mathrm{P}, \mathrm{K}, \mathrm{SO}_{4}, \mathrm{Fe}, \mathrm{B}$, and $\mathrm{Cl}$ in soil. Also both treatments similarly increased soil EC, organic matter, organic carbon, and CEC. Both composted cattle manure amendments left numerically high contents of $\mathrm{P}, \mathrm{K}, \mathrm{Mg}, \mathrm{SO}_{4}$, $\mathrm{Cu}, \mathrm{Zn}, \mathrm{Fe}, \mathrm{B}, \mathrm{Na}$, and $\mathrm{Cl}$ in soil. Also both $5 \mathrm{Ca}$ and $10 \mathrm{Ca}$ treatments increased soil $\mathrm{EC}$, organic matter, organic carbon, and CEC.

Growth and physiological responses. Compared with control, 10Co treatment significantly increased spinach leaf number (Table 2), area, FW and DW. It also increased shoot FW (Table 2) and DW, irrigation WUE but reduced DW:FW ratio. Treatment of 10Co did unaffected root DW (Table 2) but increased shoot:root ratio. The treatment of 5 Co significantly increased leaf DW (Table 2), irrigation WUE and shoot:root ratio, and decreased shoot DW:FW ratio, compared with control.

Compared with control, both $5 \mathrm{Ca}$ and $10 \mathrm{Ca}$ treatments greatly increased leaf number, area, FW and DW (Table 2). Shoot FW, DW, and irrigation WUE significantly increased under $5 \mathrm{Ca}$ and $10 \mathrm{Ca}$ treatments (Table 2). Shoot DW:FW ratio only decreased under $5 \mathrm{Ca}$ treatment (Table 2). Also $5 \mathrm{Ca}$ and $10 \mathrm{Ca}$ treatments significantly enhanced root DW and shoot:root ratio. Both $5 \mathrm{Ca}$ and $10 \mathrm{Ca}$ treatments had similar effects on leaf number and shoot:root ratio, while $10 \mathrm{Ca}$ treatment was more efficient than $5 \mathrm{Ca}$ treatment in increasing leaf area, FW and DW, shoot FW and DW, irrigation WUE and root DW.

All compost amendment similarly reduced SLA (Fig. 1B) and had no effect on leaf RWC (data not shown). Leaf succulence increased under all compost treatments (Fig. 1C). Treatment of 10Ca increased chlorophyll a content (Fig. 2A), chlorophyll b content (Fig. 2B), and total chlorophyll content (Fig. 2C). The content of chlorophyll b decreased under both $5 \mathrm{Co}$ and $10 \mathrm{Co}$ treatments (Fig. 2B).

The $\mathrm{F}_{\mathrm{v}} / \mathrm{F}_{\mathrm{m}}$ of first and third pair leaves increased only under $10 \mathrm{Ca}$ treatment, whereas that of second pair leaves increased under both $5 \mathrm{Ca}$ and $10 \mathrm{Ca}$ treatments (Fig. 3A). The photochemical yield of first and second pair leaves increased under both $5 \mathrm{Ca}$ and $10 \mathrm{Ca}$ treatments (Fig, 3B). The treatments of $5 \mathrm{Ca}$ and $10 \mathrm{Ca}$ enhanced ETR in the first pair leaves (Fig. 3C). Both $5 \mathrm{Co}$ and 10Co treatments had no effects on leaf $\mathrm{F}_{\mathrm{v}} / \mathrm{F}_{\mathrm{m}}$ (Fig. 3A), Y (II) (Fig. 3B), and ETR (Fig. 3C).

Nutritional values. Treatment of $10 \mathrm{Ca}$ increased leaf carotenoid content from 1.71 to $2.48 \mathrm{mg} \cdot \mathrm{g}^{-1} \mathrm{DW}$ (Fig. 4A). Both cotton and cattle composts reduced spinach leaf phenolic and betacyanin content. Compared with control, 5Co and 10Co treatments significantly decreased total phenolic content from 17.6 to 16.2 and $14.5 \mathrm{GAE} \mathrm{mg} \cdot \mathrm{g}^{-1} \mathrm{DW}$,
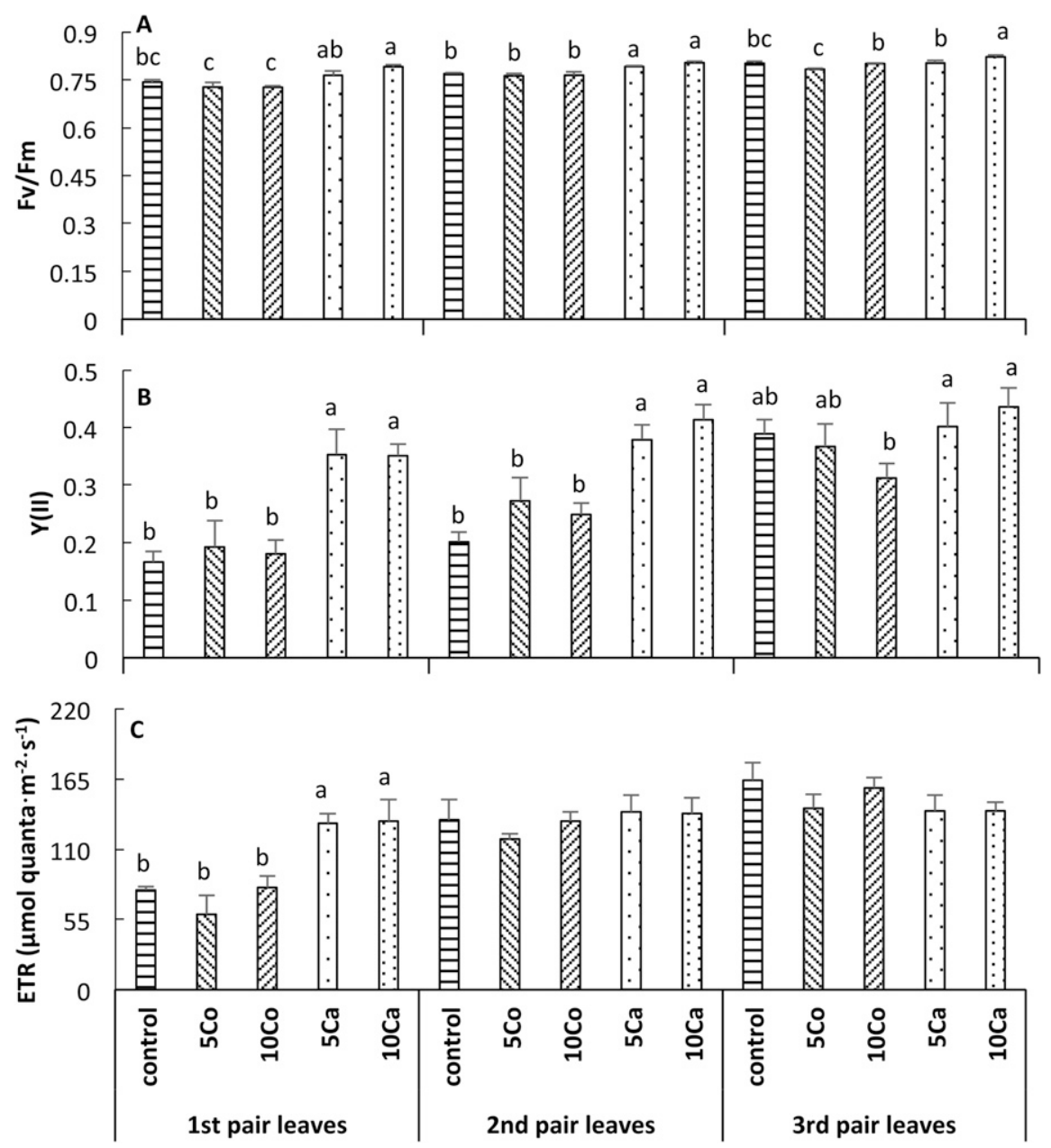

Fig. 3. Effect of composts on spinach leaf (A) photochemical efficiency $\left(F_{v} / F_{m}\right),(\mathbf{B})$ photochemical yield [Y(II)], and (C) electron transport rate (ETR) $35 \mathrm{~d}$ after transplanting. The values are means of eight replicates \pm SE. Different letters on top of bars indicate significant difference at $P \leq 0.05$ according to Duncan's multiple range test. $5 \mathrm{Co}$ or $10 \mathrm{Co}$ : soil mixed $5 \%$ or $10 \%(\mathrm{v} / \mathrm{v})$ cotton burr compost. $5 \mathrm{Ca}$ or 10Ca: soil mixed with $5 \%$ or $10 \%(\mathrm{v} / \mathrm{v})$ cattle manure compost.

respectively, and $5 \mathrm{Ca}$ and $10 \mathrm{Ca}$ treatments similarly decreased it to $14.9 \mathrm{GAE} \mathrm{mg} \cdot \mathrm{g}^{-1}$ DW (Fig. 4B). All compost treatments decreased leaf betacyanin content by $28 \%$ to $38 \%$ (Fig. 4C). Compared with control, $10 \mathrm{Co}$ and $5 \mathrm{Ca}$ treatments reduced leaf flavonoid content, and $5 \mathrm{Co}$ and $10 \mathrm{Ca}$ treatments had no significant effects (Fig. 5A). Total antioxidant capacity only significantly decreased under $10 \mathrm{Co}$ and $5 \mathrm{Ca}$ treatments (Fig. 5B). Leaf protein contents were not altered by all compost treatments except $10 \mathrm{Ca}$ treatment, which greatly increased protein content from 36 to $62 \mathrm{mg} \cdot \mathrm{g}^{-1} \mathrm{DW}$ (Fig. 6A). Amino acid content increased only under $5 \mathrm{Ca}$ and $10 \mathrm{Ca}$ treatments from 114 to 133 and $166 \mu \mathrm{mol} \cdot \mathrm{g}^{-1} \mathrm{DW}$, respectively (Fig. 6B).

\section{Discussion}

Soil fertility. The physical and chemical properties of compost have been widely studied and are usually great variable depending on several factors, such as original materials, climate, seasons of the year, quality of composting, and time of maturation
(Ouni et al., 2014; Zhang et al., 2014). Similarly the composted cotton burr and cattle manure used in the present study have variable properties in spite of similar $\mathrm{pH}, \mathrm{C}: \mathrm{N}$, and contents of $\mathrm{Ca}, \mathrm{Cu}, \mathrm{Mn}$, and B. Generally composted cattle manure have higher content of organic matter and carbon, and macro- (N, P, K, Mg, and S) and micronutrients $(\mathrm{Zn}$ and $\mathrm{B})$ than composted cotton burr, suggesting composted cattle manure is preferred as soil amendment. However, it had much higher EC than composted cotton burr, due to its high contents of $\mathrm{Na}$ and $\mathrm{Cl}$. Many studies concluded that the EC of the composts, especially composted manure, were much higher than that of agricultural soils (Hargreaves et al., 2008; Pant et al., 2012). Compost has also been reported to increase plant $\mathrm{Na}$ and $\mathrm{Cl}$ content, which may be of concern to people on low-sodium diets (Hargreaves et al., 2008; Maftoun et al., 2004). Therefore, high application rate of composted cattle manure as soil amendment is not recommended. Both composts had preferable $\mathrm{C}: \mathrm{N}$ ratio. A $\mathrm{C}: \mathrm{N}$ ratio less than 20 indicates acceptable maturity of the product while a ratio less than 15 is 

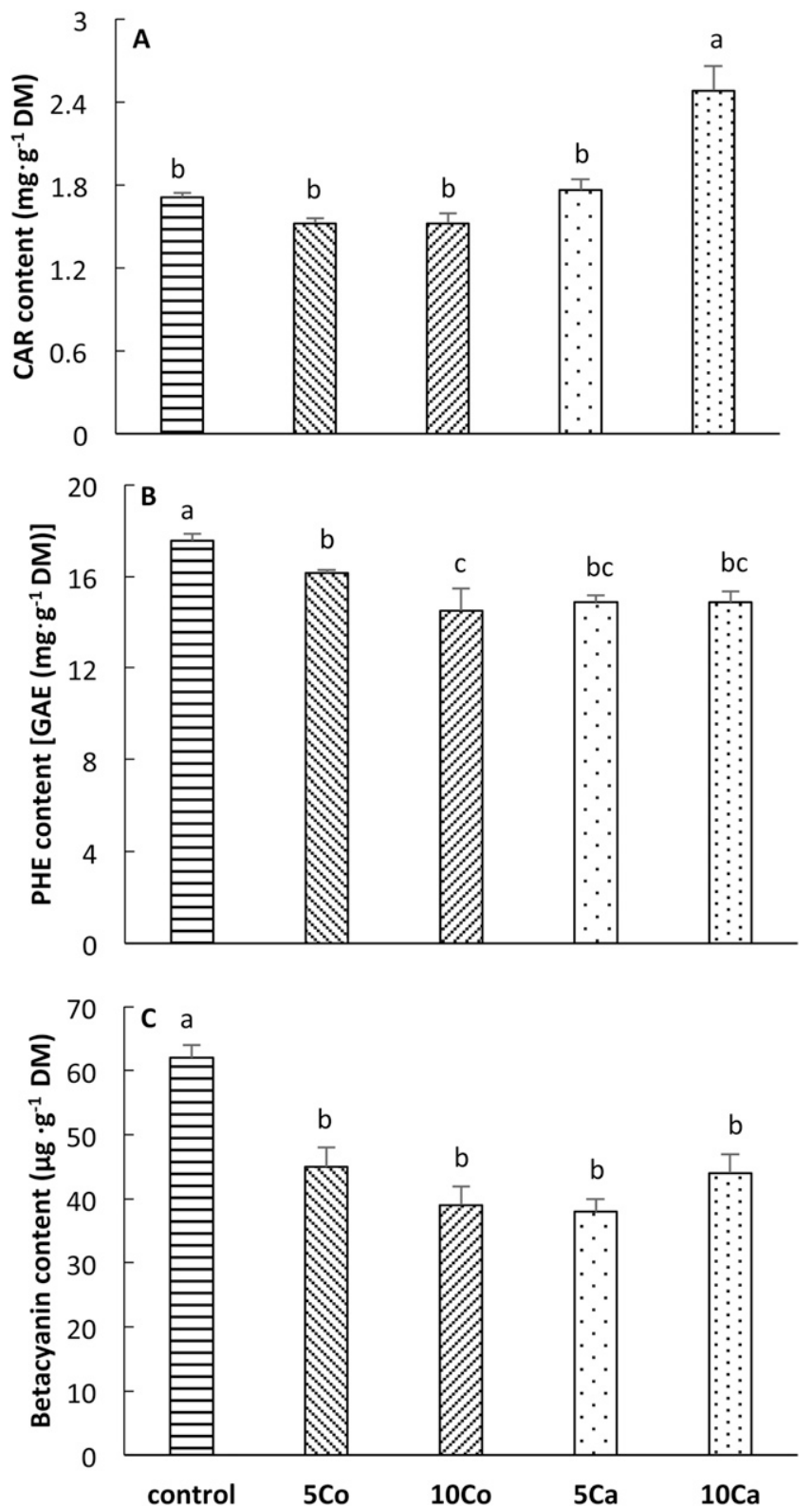

Fig. 4. Effect of composts on spinach leaf (A) carotenoid (CAR), (B) total phenolic (PHE), and (C) betacyanin content $35 \mathrm{~d}$ after transplanting. The values are means of eight replicates \pm SE. Different letters on top of bars indicate significant difference at $P \leq 0.05$ according to Duncan's multiple range test. $5 \mathrm{Co}$ or $10 \mathrm{Co}$ : soil mixed $5 \%$ or $10 \%(\mathrm{v} / \mathrm{v})$ cotton burr compost. $5 \mathrm{Ca}$ or $10 \mathrm{Ca}$ : soil mixed with $5 \%$ or $10 \%(\mathrm{v} / \mathrm{v})$ cattle manure compost. $\mathrm{GAE}=$ gallic acid equivalents.

preferred (Jimenez and Garcia, 1992; Gaur and Sadasivam, 1993).

Even after harvesting, soil with compost amendments, especially with composted cattle manure amendment, still had numerically higher content of nutrients and organic matter and carbon. Although composted cattle manure amendment greatly increased soil EC, it might not cause salinity stress for spinach growth at 5 or $10 \%$ application rate. Also, both composts increase soil CEC, which has a significant effect on soil fertility. The clay mineral and organic matter components of soil have negatively charged sites on their surfaces which adsorb and hold cations. This electrical charge is critical to the supply of nutrients to plants because many nutrients exist as cations. In general terms, soils with high CEC are more fertile because they retain more cations (McKenzie et al., 2004). Together, the results indicate that composted cattle manure and cotton burr could be used as soil amendment at $5 \%$ or $10 \%$ rate to improve soil fertility.

Growth and physiological responses. Spinach growth, both shoot and root, was greatly enhanced by composted cattle manure, especially at $10 \%$ mix rate, as indicated by increased leaf number, area, FW and DW, shoot FW and DW, and root DW. Composted cotton burr also improved spinach growth but only at $10 \%$ mix rate with less efficiency than composted cattle manure. The higher efficiency of composted cattle manure than that of composted cotton burr might partly result from its high contents of organic matter and nutrients. Increased shoot:root ratio indicated that shoot growth was more favorably influenced by compost amendment than root growth. Compost contains micro- and macronutrients, organic matter, hormone-like substances, biotic agents, carbon dioxide, nitric oxide, and many others (Hargreaves et al., 2008). These components can synergistically act in affecting numerous physiological and biochemical metabolism including uptake and transportation of water and mineral, enzyme activation, osmotic potential, photosynthesis, hormone balance, and antioxidant defences. Organic matter can promote root growth which increases water and nutrient uptake from soil, mineralizes nitrogen and carbon, stabilizes soil structure which improves soil aggregation, permeability and infiltration of water into soil, and improves soil properties such as CEC and acidity (Emmerling et al., 2010; Hargreaves et al., 2008). Compost can improve soil microorganism and colonization of root by arbuscular mycorrhizal fungi (Montalba et al., 2010; Suárez-Estrella et al., 2007). Growth enhancement by compost amendment might also attribute to its humic substances (Hargreaves et al., 2008). Humic acid can stimulate plant growth by improving soil $\mathrm{Fe}^{2+}$ and $\mathrm{Zn}^{2+}$ availability and redistribution of cytokinins and polyamines (Mora et al., 2010; Tartoura and Youssef, 2011). In addition, compost amendment can facilitate plant antioxidant systems to reduce oxidative damages (Tartoura and Youssef, 2011) and adjust plant hormone balance to prompt plant growth (Ouni et al., 2014).

Both composted cattle manure and cotton burr increased spinach irrigation WUE, which might result at least partly from reduced SLA and improved soil properties, such as WHC. All compost treatments reduced SLA in the present study and reduction of SLA is assumed to improve WUE, because thicker leaves usually have a greater photosynthetic capacity than thinner leaves (Liu and Stützel, 2004). Also reduced SLA, a function of leaf dry matter content and thickness, and increased succulence indicated that compost as soil amendment not only increased spinach production but also improved its quality.

Chlorophyll content increased only under $10 \mathrm{Ca}$ treatment, and actually composted cotton burr slightly reduced chlorophyll content $(P=0.0748$ and 0.0812 for $5 \mathrm{Co}$ and $10 \mathrm{Co}$ treatments, respectively). Consistent with the present study, Tartoura and Youssef (2010) found that composted manure increased chlorophyll content in cucumber leaves. There are very limited reports on the photochemistry of photosystem II as affected by compost amendment. In this study, composted cotton burr had no effect while composted cattle manure improved photochemistry of photosystem II of mature leaves. For example, composted cattle manure enhanced $\mathrm{F}_{\mathrm{v}} / \mathrm{F}_{\mathrm{m}}$ and Y (II) of both first and second pair leaves, and ETR of the first pair leaves, whereas had no effect on the third pair leaves which were the largest leaves of each plant. Parameters 

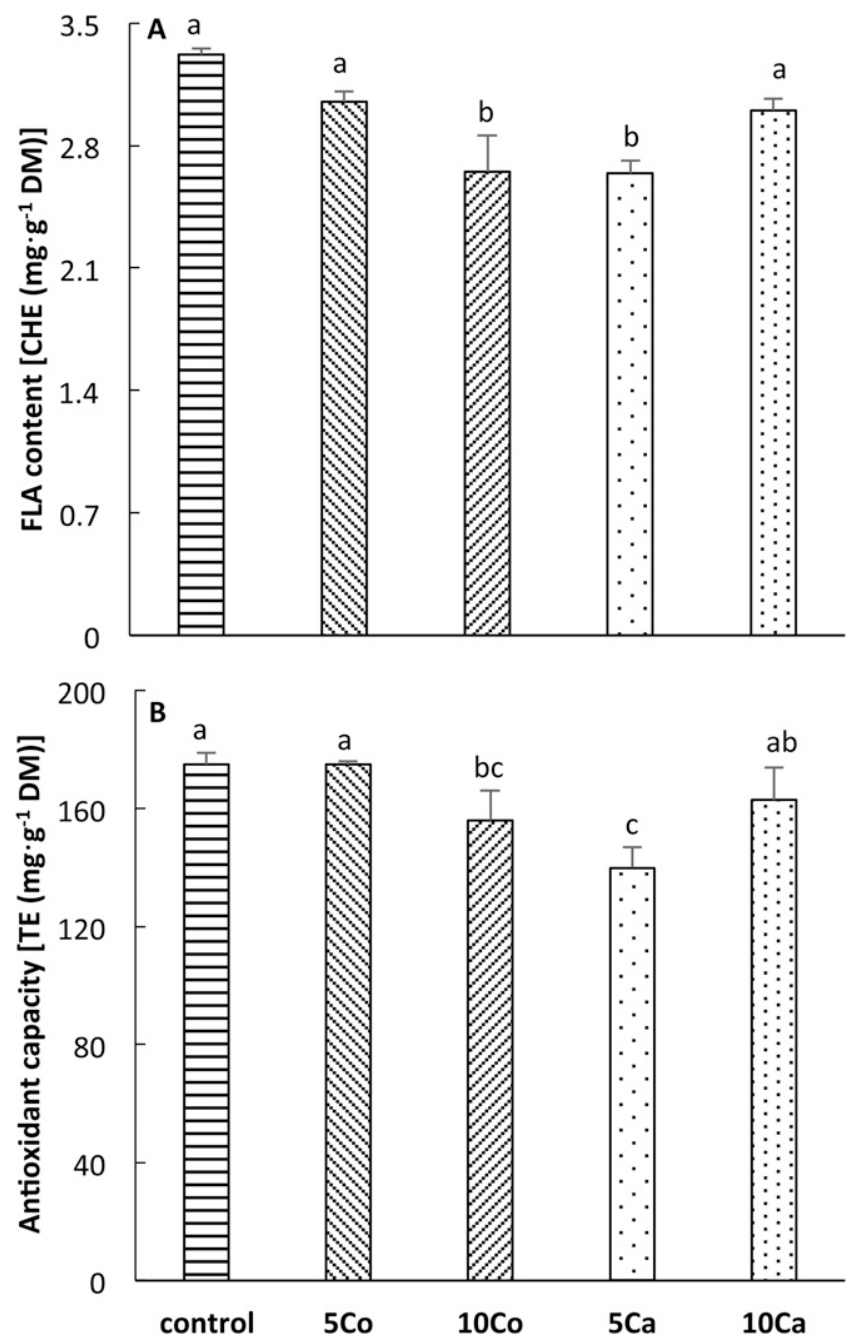

Fig. 5. Effect of composts on spinach leaf (A) flavonoid content (FLA) and (B) total antioxidant capacity $35 \mathrm{~d}$ after transplanting. The values are means of eight replicates \pm SE. Different letters on top of bars indicate significant difference at $P \leq 0.05$ according to Duncan's multiple range test. $5 \mathrm{Co}$ or $10 \mathrm{Co}$ : soil mixed $5 \%$ or $10 \%(\mathrm{v} / \mathrm{v})$ cotton burr compost. $5 \mathrm{Ca}$ or $10 \mathrm{Ca}$ : soil mixed with $5 \%$ or $10 \%(\mathrm{v} / \mathrm{v})$ cattle manure compost. $\mathrm{CHE}=(+)$-catechin hydrate equivalents; $\mathrm{TE}=$ trolox equivalents.

related to photochemistry of photosystem II, such as $\mathrm{F}_{\mathrm{v}} / \mathrm{F}_{\mathrm{m}}, \mathrm{Y}$ (II), and ETR, are commonly used as indicators for leaf senescence (Adams et al., 1990; Lima et al., 1999). The result suggested that composted cattle manure could delay the senescence of mature leaves.

Nutritional values. Carotenoids have long been recognized as essential nutrients and important health-beneficial compounds (Fraser and Bramley, 2004). Its content increased only under $10 \mathrm{Ca}$ treatment in the present study. Phenolics are a class of secondary metabolites which play a key role as antioxidants. In the present study, all compost amendments decreased total phenolic content by $8 \%$ to $17 \%$ and betacyanin content by $28 \%$ to $38 \%$. The most important group of phenolics in plants is flavonoids which have attracted considerable interest due to their nutritional values (Guo et al., 2011; Maimoona et al., 2011). Previous study indicated that phenolic and flavonoid contents in spinach were enhanced by low fertilizer level (Xu and Mou, 2016). In the present study, the response pattern of antioxidant capacity although it reduced the content of total phenolics and betacyanin. Compost as soil amendment for spinach production in the field might be an efficient strategy for water savings, organic farming as well as recycling of organic waste materials. However, the influence of compost application on spinach growth and quality in contrast to the impact of synthetic fertilizer application need to be investigated. Further research should also be conducted to investigate its long-term effect and optimize its application rates in the field.

\section{Literature Cited}

Adams, W.W., III, K. Winter, U. Schreiber, and P. Schramel. 1990. Photosynthesis and chlorophyll fluorescence characteristics in relationship to changes in pigment and element composition of leaves of Platanus occidentalis L. during autumnal leaf senescence. Plant Physiol. 92:1184-1190.

Albiach, R., R. Canet, F. Pomares, and F. Ingelmo 2000. Microbial biomass content and enzymatic activities after the application of organic amendments to a horticultural soil. Bioresour. Technol. 75:43-48.

Barr, H.D. and P.E. Weatherley. 1962. A reexamination of the relative turgidity technique for estimating water deficit in leaves. Austral. J. Biol. Sci. 15:413-428.

Benzie, I.F.F. and J.J. Strain. 1996. The ferric reducing ability of plasma (FRAP) as a measure of "antioxidant power": The FRAP assay. Anal. Biochem. 239:70-76.

Birkhofer, K., T.M. Bezemer, J. Bloem, M Bonkowski, S. Christensen, D. Dubois, F. Ekelund, A. Fliebach, L. Gunst, K. Hedlund, P. Mäder, J. Mikola, C. Robin, H. Setälä, F. Tatin-Froux, W.H. van der Putten, and S. Scheu. 2008. Long-term organic farming fosters below and aboveground biota: Implications for soil quality, biological control and productivity. Soil Biol. Biochem. 40:2297-2308.

Bradford, M.M. 1976. A rapid and sensitive method for the quantitation of microgram quantities of protein utilizing the principle of protein-dye binding. Anal. Biochem. 72:248254.

Dewanto, V., X. Wu, K.K. Adom, and R.H. Liu. 2002. Thermal processing enhances the nutritional value of tomatoes by increasing total antioxidant activity. J. Agr. Food Chem. 50:3010-3014.

D'Hose, T., M. Cougnon, A. De Vliegher, K. Willekens, E. Van Bockstaele, and D. Reheul. 2012. Farm compost application: Effects on crop performance. Compost Sci. Util. 20: 49-56.

Emmerling, C., T. Udelhoven, and R. Schneider. 2010. Long-lasting impact of biowaste-compost application in agriculture on soil-quality parameters in three different crop-rotation systems. J. Plant Nutr. Soil Sci. 173:391-398.

Evans, G.C. 1972. The quantitative analysis of plant growth. University of California Press, Berkeley, CA.

Fraser, P.D. and P.M. Bramley. 2004. The biosynthesis and nutritional uses of carotenoids. Prog. Lipid Res. 43:228-265.

Gaur, A.C. and K.V. Sadasivam. 1993. Theory and practical considerations of composting organic wastes, p. 1-20. In: P.K. Thampan (ed.). Organics in soil health and crop production.

Guo, T., L. Wei, J. Sun, C. Hou, and L. Fan. 2011. Antioxidant activities of extract and fractions 

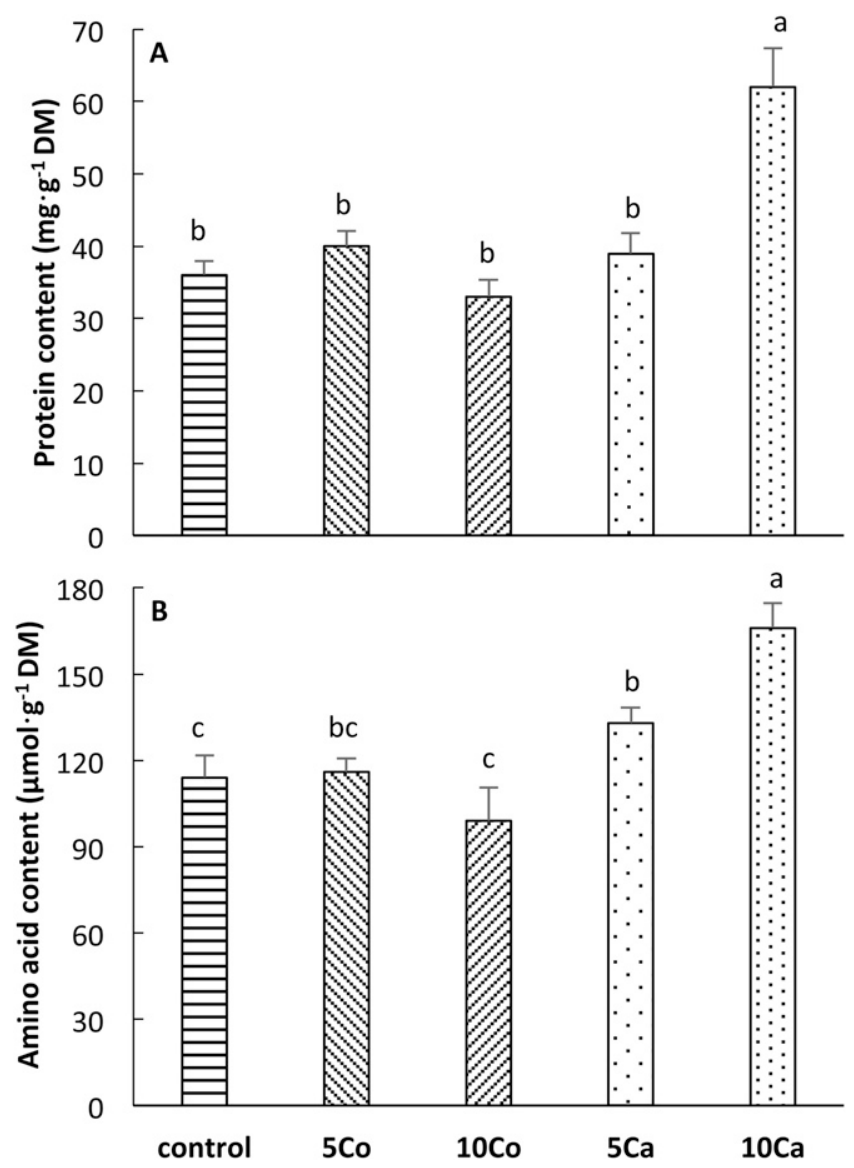

Fig. 6. Effect of composts on spinach leaf (A) protein and (B) amino acid content $35 \mathrm{~d}$ after transplanting. The values are means of eight replicates \pm SE. Different letters on top of bars indicate significant difference at $P \leq 0.05$ according to Duncan's multiple range test. 5Co or $10 \mathrm{Co}$ : soil mixed $5 \%$ or $10 \%$ $(\mathrm{v} / \mathrm{v})$ cotton burr compost. $5 \mathrm{Ca}$ or $10 \mathrm{Ca}$ : soil mixed with $5 \%$ or $10 \%(\mathrm{v} / \mathrm{v})$ cattle manure compost.

from Tuber indicum Cooke \& Massee. Food Chem. 127:1634-1640.

Hargreaves, J.C., M.S. Adl, and P.R. Warman. 2008. A review of the use of composted municipal solid waste in agriculture. Agr. Ecosyst. Environ. 123:1-14.

Herencia, J.F., P.A. García-Galavís, J.A.R. Dorado, and C. Maqueda. 2011. Comparison of nutritional quality of the crops grown in an organic and conventional fertilized soil. Sci. Hort. 129:882-888.

Herrick, J.E. 2000. Soil quality: An indicator of sustainable land management? Appl. Soil Ecol. 15:75-83.

Jimenez, E.I. and V.P. Garcia. 1992. Determination of maturity indexes for city refuses composts. Agr. Ecosyst. Environ. 38:331-343.

Kirschenmann, F. 2010. Alternative agriculture in an energy- and resource-depleting future. Renew. Agr. Food Syst. 25:85-89.

Lichtenthaler, H.K. 1987. Chlorophylls and carotenoids-pigments of photosynthetic biomembranes. Methods Enzymol. 148:350-382.

Lima, J.D., P.R. Mosquim, and F.M. Da Matta. 1999. Leaf gas exchange and chlorophyll fluorescence parameters in Phaseolus vulgaris as affected by nitrogen and phosphorus deficiency. Photosynthetica 37:113-121.

Liu, F. and H. Stützel. 2004. Biomass partitioning, specific leaf area, and water use efficiency of vegetable amaranth (Amaranthus spp.) in response to drought stress. Sci. Hort. 102:15-27.

Liu, X., S.J. Herbert, A.M. Hashemi, X. Zhang, and G. Ding. 2006. Effects of agricultural management on soil organic matter and carbon transformation - A review. Plant Soil Environ. 52:531-543.

Longstreth, D.J. and P.S. Nobel. 1979. Salinity effects on leaf anatomy consequences for photosynthesis. Plant Physiol. 63:700-703.

Maftoun, M., F. Moshiri, N. Karimian, and A. Ronaghi. 2004. Effects of two organic wastes in combination with phosphorus on growth and chemical composition of spinach and soil properties. J. Plant Nutr. 27:1635-1651.

Maimoona, A., I. Naeem, Z. Saddiqe, and K. Jameel. 2011. A review on biological, nutraceutical and clinical aspects of French maritime pine bark extract. J. Ethnopharmacol. 133:261-277.

McKenzie, N.J., D.J. Jacquier, R.F. Isbell, and K.L. Brown. 2004. Australian soils and landscapes: An illustrated compendium. CSIRO Publishing: Collingwood, Victoria.

McLauchlan, K. 2006. The nature and longevity of agricultural impacts on soil carbon and nutrients: A review. Ecosystems 9:1364-1382.

Mehta, C.M., U. Palni, I.H. Franke-Whittle, and A.K. Sharm. 2014. Compost: Its role, mechanism and impact on reducing soil-borne plant diseases. Waste Mgt. 34:607-622.
Montalba, R., C. Arriagada, M. Alvear, and G.E Zúniga. 2010. Effects of conventional and organic nitrogen fertilizers on soil microbial activity, mycorrhizal colonization, leaf antioxidant content, and Fusarium wilt in highbush blueberry (Vaccinium corymbosum L.). Sci. Hort. 125:775-778.

Montemurro, F., A. Fiore, G. Campanalli, C. Ciaccia, D. Ferri, M. Maiorana, and M. Diacono. 2015. Yield and performance and soil properties of organically fertilized fodder crop. J. Plant Nutr. 38:1558-1572.

Mora, V., E. Bacaicoa, A.-M. Zamarrenno, E Aguirre, M. Garnica, M. Fuentes, and J.-M. García-Mina. 2010. Action of humic acid on promotion of cucumber shoot growth involves nitrate-related changes associated with the root-to-shoot distribution of cytokinins, polyamines and mineral nutrients. J. Plant Physiol. 167:633-642.

Ouni, Y., A. Albacete, E. Cantero, A. Lakhdar, C. Abdelly, F. Pérez-Alfocea, and Z. Barhoumi. 2014. Influence of municipal solid waste (MSW) compost on hormonal status and biomass partitioning in two forage species growing under saline soil conditions. Ecol. Eng. 64:142-150.

Pant, A.P., J.K.T. Radovich, N.V. Hue, and R.E. Paull. 2012. Biochemical properties of compost tea associated with compost quality and effects on pakchoi growth. Sci. Hort. 148:138-146.

Reeves, D.W. 1997. The role of soil organic matter in maintaining soil quality in continuous cropping systems. Soil Tillage Res. 43:131-167.

Schwartz, S.J. and J.H. von Elbe. 1980. Quantitative determination of individual betacyanin pigments by high-performance liquid chromatography. J. Agr. Food Chem. 28:540-543.

Slinkard, K. and V.L. Singleton. 1997. Total phenol analysis: Automation and comparison with manual methods. Amer. J. Enol. Viticult. 28:49-55

Suárez-Estrella, F., C. Vargas-García, M.J. Lópeza, C. Capel, and J. Moreno. 2007. Antagonistic activity of bacteria and fungi from horticultural compost against Fusarium oxysporum f. sp. Melonis. Crop Prot. 26:46-53.

Tartoura, K.A.H. and S.A.G. Youssef. 2010. Effect of compost on the antioxidant defense systems of cucumber (Cucumis sativus L.) against cadmium toxicity. Anna. Agr. Sci. (Cairo) 55:191-203.

Tartoura, K.A.H. and S.A.G. Youssef. 2011. Stimulation of ROS-scavenging systems in squash (Cucurbita pepo L.) plants by compost supplementation under normal and low temperature conditions. Sci. Hort. 130:862-868.

Whalen, J.K., Q. Hu, and A. Liu. 2003. Compost applications increase water-stable aggregates in conventional and no-tillage systems. Soil Sci. Soc. Amer. J. 67:1842-1847.

$\mathrm{Xu}, \mathrm{C}$. and B. Mou. 2016. Spinach responses to salinity and nutrient deficiency in growth, physiology and nutritional values. J. Amer. Soc. Hort. Sci. 141:12-21.

Yokoyama, S. and J.I. Hiramatsu. 2003. A modified ninhydrin reagent using ascorbic acid instead of potassium cyanide. J. Biosci. Bioeng. 95:204-205.

Zhang, X., Y. Cao, Y. Tian, and J. Li. 2014. Shortterm compost application increases rhizosphere soil carbon mineralization and stimulates root growth in long-term continuously cropped cucumber. Sci. Hort. 175:269-277. 